\title{
REVIEW
}

\section{Physiological implications of pituitary trophic activity}

\author{
A Levy \\ University Research Centre for Neuroendocrinology, University of Bristol, Bristol Royal Infirmary, Marlborough Street, Bristol BS2 8HW, UK \\ (Requests for offprints should be addressed to A Levy; Email: a.levy@bris.ac.uk)
}

\begin{abstract}
A complete inventory of pituitary trophic responses depends on precise estimates of mitotic activity and apoptotic events, and accurate characterization and quantification of pituitary cell subtypes irrespective of previous and current physiological demand. For a discrete structure that has been so extensively studied, it is disappointing but perhaps not surprising that none of these measures is available and therefore that the relative contributions to changes in the proportions of pituitary cellular subpopulations of trophic activity, differentiation of pluripotent cells and variations in the secretory profiles of apparently committed cells remain almost impossible to determine. To fully appreciate the extent of this dilemma, it should be remembered that conservative estimates of the proportion of corticotrophs in the rat anterior pituitary under basal conditions vary over twofold and that it is still not clear whether the apparent threefold increase in
\end{abstract}

mammotrophs during pregnancy is the result of maturation of uncommitted cells, transdifferentiation of other cells such as somatotrophs, cell division, or a mixture of all three. Equally, while it has been known for some time that adrenalectomy results in a transient increase in anterior pituitary mitotic activity and appropriately timed supraphysiological glucocorticoid replacement with a wave of apoptosis, the precise identity of the cells involved in both of these responses is open to question. Thus, although many of the physiological stimuli associated with apparent changes in the proportions of pituitary cellular subpopulations are known, the precise mechanism of the changes and the consequences of the same remain obscure. This review summarizes the limited literature on pituitary trophic activity and asks what, if anything, analysis of pituitary trophic activity using current technology can tell us.

Journal of Endocrinology (2002) 174, 147-155

\section{Introduction}

In practice, the accuracy of immunocytochemical quantification is limited by the use of secreted peptides as markers under circumstances known to produce dramatic changes in hormone content and by subtle, yet potentially highly significant, technical constraints. Quantitative immunochemistry is hampered by cell clumping, which frustrates accurate differentiation of individual cells and variations in cellular shape and size that limit the validity of extrapolating cell counts derived from transection planes into tissue volume. The potential for transdifferentiation (Horvath et al. 1990, Kineman et al. 1992, Vidal et al. $2000,2001)$ or at least marked changes in the relative proportions of peptide markers in what seem increasingly likely to be pleuripotent cells further undermines the interpretation of immunocytochemical counting indices even if the methodology and antibodies and other reagents used could be completely standardized. The resulting variability in estimates of specific cell types is exemplified by reports of the prevalence of immunocytochemically defined corticotroph cells in the rat pituitary. Although these tend to be stellate rather than compact, as corticotrophs constitute one of the smaller and more discrete cellular subpopulations, they should be amongst the most straightforward to quantify. Even so, estimates of corticotroph numbers in normal young rats under unstimulated conditions vary from less than 3\% (Dada et al. 1984, Taniguchi et al. 1995) to more than 20\% (Castro et al. 1995) with a greater than twofold difference in approximations even if these extremes are excluded (4.5 $\pm 0 \cdot 3 \%$ (Gertz et al. 1987), $4 \cdot 7 \pm 0 \cdot 28 \%$ (Nolan et al. 1998), $6 \cdot 2 \pm 0 \cdot 3 \%$ (Asa et al. 1992a), 7-10\% (Childs 1987) and $9 \cdot 7 \pm 1 \cdot 0 \%$ (Westlund et al. 1985)). Whether, in addition to differences in age, sex, strain and animal handling, this variability in part reflects disparities in absolute corticotroph numbers or alterations in total cell numbers in the pituitary is unanswered and very difficult to address.

Accurate counting is even more demanding with the prevalent parenchymal subtypes such as somatotrophs and mammotrophs owing to the proximity of similar cells and larger scale topographical organization. Accordingly, in 
man, reports of basal mammotroph prevalence in nulliparous females and adult males vary from less than $9 \%$ to over 30\% (Asa et al. 1982) - a range within which important changes in cell population sizes in response to physiological stimuli could clearly be lost. Furthermore, mitotic markers such as the proliferation-associated nuclear antigen Ki-67 and S phase-incorporated bromodeoxyuridine (Gratzner 1982) both rely on immunocytochemical detection, and whilst actively cycling cells can be recognized directly in tissue sections during metaphase or identified autoradiographically after $\mathrm{S}$ phase exposure to tritiated thymidine, absolute quantification of trophic activity, even if no attempt is made to specifically identify the secretory subtype of the cells involved, is also a formidable task.

Flow cytometry has been used to study pituitary cell cycle kinetics (Toni \& Vitale 2000) and is capable of yielding relatively pure cellular populations from dispersed pituitary cells after suitable stimulation (Wynick et al. $1990 a, b)$. However, the technique is insensitive and it cannot realistically be used to quantify different cell types as it suffers many of the technical constraints and much of the same variability as immunochemistry.

Timed colchicine-induced mitotic arrest to extract mitotic rate information from fixed tissue sections (stathmokinetic analysis) can be used to provide a surrogate estimate of the relationship between apoptotic event prevalence and apoptotic rate (Kolopp et al. 1992, Nolan et al. 1998, 1999) but the poorly specified duration of cell death labelling using terminal deoxyribonucleotidyl transferasemediated dUTP nick end labelling (Mangili et al. 1999) or protein markers (Kulig et al. 1999) prevents dynamic data about these processes being extrapolated from prevalence measurements. The findings that most mitotic activity occurs in cells that are not immunopositive for any of the pituitary hormones (Dada et al. 1984, Carbajo-Perez \& Watanabe 1990), that the mitotic response of the pituitary to adrenalectomy is largely confined to cells that are not immunocytochemically identifiable as corticotrophs (Taniguchi et al. 1995) and that the fleeting, but quantitatively impressive, apoptotic response of adrenalectomized rats to glucocorticoids must, numerically, involve noncorticotroph cells (Nolan et al. 1998) adds further to the complexity. In short, the cellular subtypes in the pituitary that show trophic activity cannot be directly recognized with any facility or their identities surmised from the prevailing physiological circumstances by conjecture alone. The following brief overview of published data regarding dynamic changes in pituitary cell populations (the paucity of which reflects these difficulties) should therefore be considered with these limitations in mind.

\section{The effects of age on pituitary trophic activity}

Organogenesis is a primary but transient trophic demand in early life. From around $5 \cdot 5 \pm 0 \cdot 1 \mathrm{mg}$ (mean \pm S.E.) in

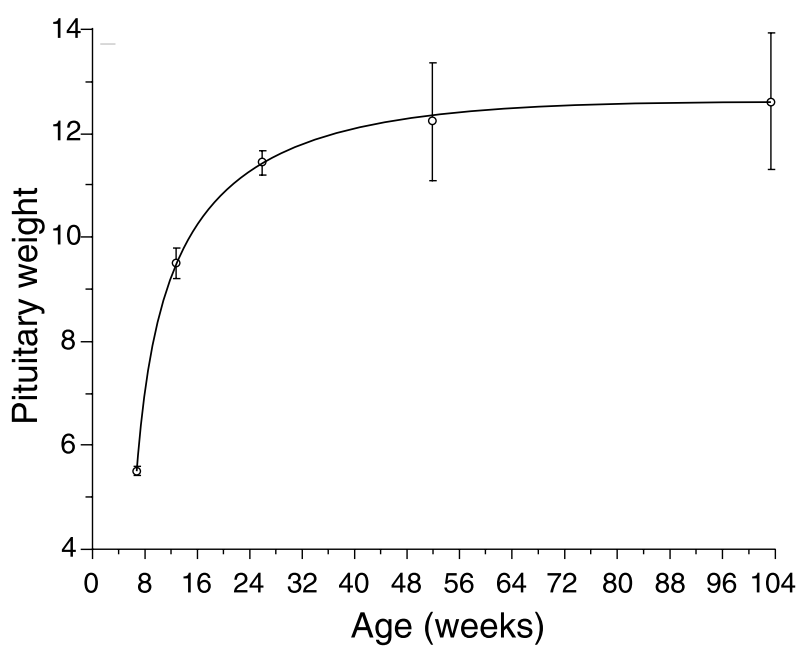

Figure 1 Age-related changes in the intact male Wistar rat pituitary. Mean pituitary wet weight \pm S.E. is shown.

weight at 6 weeks, in our animal facility and fed standard laboratory diet (which is designed to modestly restrict growth), the male Wistar rat pituitary doubles in weight to $11 \cdot 4 \pm 0.2 \mathrm{mg}$ at 6 months and increases by a further $10 \%$ over the next 18 months, to $12 \cdot 6 \pm 1.3 \mathrm{mg}$ by 24 months (Fig. 1). A combination of enzymatic cellular dispersal, direct cell counting, DNA determinations and electron microscopic differential cell counting has provided an estimate of total anterior pituitary cell numbers in rats at this age (Surks \& DeFesi 1977). As the proportion of the pituitary taken up by vascular and connective tissue structures and the overall size and packing of parenchymal cells vary little over this time, this represents an increase in cell numbers from around $1.4 \times 10^{6}$ at 6 weeks to $3.3 \times 10^{6}$ at 2 years. Using timed colchicine-induced mitotic arrest with accurate quantification of the prevalence of mitotic figures, it is apparent that between 6 weeks and 16 months of age, and perhaps throughout life, pituitary mitotic activity exceeds that required for organ growth. On average, just under $60 \%$ of the directly measured cell production contributes to overall pituitary growth between the ages of 6 weeks and 13 weeks. Between 13 weeks (when turnover rate averages 1.58\% per day) and 6 months, $14 \%$ of nascent cells contribute to increased pituitary weight. Between 6 months and 1 year, less than $4 \cdot 6 \%$ of cell production contributes to pituitary growth, and between 16 months and 2 years, less than 3\% of cell production contributes to growth (LA Nolan \& A Levy, unpublished findings). Thus, while the absolute rate of cell turnover decreases markedly with time, an increasing proportion of cellular turnover is not related to organogenesis per se. Studies in beagle dogs concur with a general reduction in pituitary cell turnover with age (Kolopp et al. 1992). Whether cell turnover in the rat pituitary declines continuously from the time of its first 


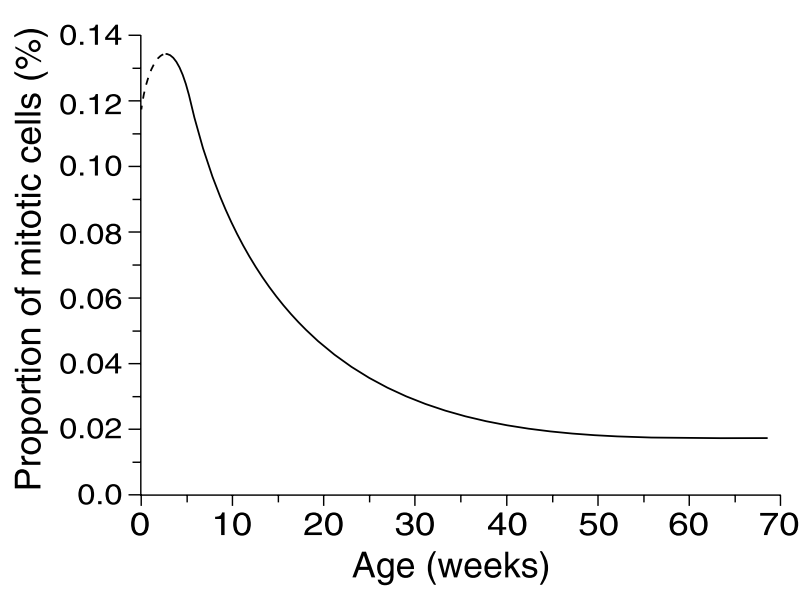

Figure 2 Age-related changes in anterior pituitary mitotic activity in intact, untreated male Wistar rats shown as the absolute proportion of cells in histologically overt mitosis in $2 \mu \mathrm{m}$ thick tissue sections (percentage of parenchymal cells). Based on direct observations between 6 and 68 weeks (Nolan et al. 1999), the initial (broken) line is speculation based on findings from McNicol \& Carbajo-Perez (1999).

appearance in foetal life (Friend 1979) or accelerates in early post-natal life to a peak at about 4 weeks before subsequently declining (Shirasawa \& Yoshimura 1982, McNicol \& Carbajo-Perez 1999) is not yet entirely clear, although the latter evidence is perhaps more secure (denoted by the discontinuous line segment in Fig. 2 (Nolan et al. 1999)). It has also been suggested that different cell subpopulations have different rates of basal mitotic activity at different ages with, for example, a steadily decreasing mitotic rate for corticotrophs, apart from a peak just before 3 weeks of age and a progressive increase in somatotroph and mammotroph mitotic activity during the first 10 weeks of life (Shirasawa \& Yoshimura 1982).

In addition to changes in rate of cell division, in female Wistar rats at least, there appears to be an age-related change in the proportion of cell types with mammotrophs increasing and pure somatotrophs decreasing with senescence (Shinkai et al. 1995). At the same time, the number of mammosomatotrophs increases more than tenfold in rats older than 21 months compared with rats less than 13 months old (Shinkai et al. 1995). The precise extent to which this represents a true change in cell proportions or less polarized hormone gene expression in chronically pleuripotent, terminally differentiated cells remains a conundrum. In man, despite a clear age-related decline in growth hormone $(\mathrm{GH})$ secretion, there does not appear to be a significant decline in somatotroph cell mass (Thorner et al. 1997).

\section{Circadian rhythmicity of trophic activity}

Several studies have suggested that there is a circadian rhythm in mitotic activity in the rat pituitary. Whether peak activity occurs during the night (Carbajo-Perez et al. 1991, Oishi et al. 1993) or during the day, or as one peak of mitotic activity (McNicol \& Carbajo-Perez 1999) or two (Nouet \& Kujas 1975) is unclear. Differences in age, sex and breed of rats aside, the very low prevalence of mitotic figures and the unpredictable effects of stress in different holding facilities is likely to make this issue hard to resolve. The observation is of considerable interest, nevertheless, as the presence of circadian changes implies that, in addition to intrinsically driven mitotic and apoptotic activity, the pituitary is closely coupled to acute hypothalamic trophic influences.

\section{Pregnancy and the gonadal axis}

The volume of the adult human pituitary appears to be slightly greater in females than males in vivo as estimated using magnetic resonance imaging reconstruction (Denk et al. 1999) and also in autopsy series (Bergland et al. 1968), particularly following multiple pregnancies (Asa et al. 1982). During pregnancy itself, the human pituitary enlarges by about $20-36 \%$ and peaks in size several days post-partum (Gonzalez et al. 1988, Elster et al. 1991, Dinc et al. 1998). Whether these changes indicate trophic activity or changes in vascularity and/or cell size is unknown. In 10-week-old rats it has been found that anterior pituitary mitotic activity in females is twice as high as that found in males overall, with a peak of mitotic activity occurring in oestrus (Oishi et al. 1993). The distribution of mitotic activity amongst the different pituitary cell types is similar between the sexes, with mammotrophs accounting for the highest proportion of mitotic activity overall (Oishi et al. 1993). In beagle dogs, no sexual dimorphism in basal trophic activity in the pituitary gland has been found (Kolopp et al. 1992) and, predictably, no human data are available.

Stathmokinetic analysis in combination with luteinizing hormone immunochemistry has been used to demonstrate a tenfold increase in proliferating gonadotrophs 1-2 weeks after orchidectomy, resulting in a temporary increase in gonadotrophs in rats (Inoue et al. 1985). There is no evidence, however, that under normal circumstances continuous exposure to hypothalamic gonadotrophinreleasing hormone has any trophic action on gonadotrophs in vivo or in organ culture (Khar et al. 1978, Pawlikowski et al. 1978a), although an indirect gonadotroph-dependent trophic effect on lactotrophs and corticotrophs has been suggested (Denef et al. 1990, Tilemans et al. 1992).

Oestradiol significantly increases tritiated thymidine uptake by rat anterior pituitary cells in vitro (Pawlikowski et al. 1997), and case reports have associated the apparent progression of a human microprolactinoma to a macroprolactinoma (Garcia \& Kapcala 1995) and the development of invasive characteristics of a macroprolactinoma (Bevan et al. 1989b) with prolonged oestrogen treatment. It is still 
not clear whether the marked increase in pituitary prolactin-secreting cells during pregnancy from 15\% antenatally to 50\% at term (Haggi et al. 1986) and restoration to nulliparous levels within 7-21 days (if suckling does not take place) is mediated in part by mitosis and apoptosis, or whether transdifferentiation of somatotrophs into bihormonal mammosomatotrophs (Vidal et al. 2001) or complete transformation into lactotrophs via the mammosomatotroph phenotype is entirely responsible for the changes seen (Stefaneanu et al. 1992).

\section{The thyroid axis and trophic activity}

Prolonged hypothyroidism in some patients produces a dramatic but reversible increase in pituitary size, sometimes with few other systemic symptoms of hypothyroidism (Bilaniuk et al. 1985, Abram et al. 1992, Alkhani et al. 1999, Brandle \& Schmid 2000, Vidal et al. 2000). In the thyroidectomized rat model, there is a fairly consistent $25 \%$ increase in total cell numbers, with a fourfold increase in the number of thyrotrophs and concomitant reduction in the number of immunocytochemically defined somatotrophs by almost two-thirds compared with intact animals (Surks \& DeFesi 1977).

Thyrotrophin-releasing hormone (TRH)-induced pituitary cell proliferation has been demonstrated in vivo (Kunert-Radek \& Pawlikowski 1975, Pawlikowski \& Slowinska-Klencka 1994) and in organ (Pawlikowski et al. 1975) and cell culture in vitro (Pawlikowski et al. 1975). TRH-induced tritiated thymidine incorporation in vitro is inhibited by thyroxine (Pawlikowski et al. 1975) and blocked completely by somatostatin (Pawlikowski et al. 1978c). Thyroxine itself has no effect on adenohypophyseal cell proliferation in vitro (Pawlikowski et al. 1975) but in thyroidectomized and chronically hypothyroid rats, in which additional exogenous TRH alone is ineffective in inducing a proliferative response, thyroxine replacement produces a dose-dependent increase in mitotic activity in somatotrophs and (in some respects paradoxically) in thyrotrophs, and restores the ability of TRH to induce mitotic activity at least in somatotrophs (Quintanar-Stephano \& Valverde 1997).

It is still not entirely clear whether there is a direct effect of TRH on tritiated thymidine incorporation by thyrotrophs as such a response has not been detected by double labelling of monolayer anterior pituitary cell cultures exposed to TRH (Komolov et al. 1978). Thus it is conceivable that the apparent fourfold increase in the number of thyrotrophs in thyroidectomized rats (Surks \& DeFesi 1977) is mediated, in part, by transdifferentiation from the somatotroph and thyrotroph lineages, as well as appearing to result artefactually from a relative reduction in the somatotroph population. As long-term incubation with TRH abolishes the growth-inhibitory effects of dopamine on the $\mathrm{GH} 4 \mathrm{C} 1$ prolactin- and $\mathrm{GH}$-secreting rat pituitary tumour-derived cell line transfected with the short form of the D2 dopamine receptor, part of the growth-modulating effects of TRH may be mediated through indirect inhibitory effects on D2 dopamine receptor function (Senogles 1994). It is unclear whether data derived from a cell line can usefully inform the situation in vivo, but intuitively such an effect on D2 dopamine receptor function may be, in part, responsible for the stimulatory effect of TRH on proliferation in pituitary intermediate lobe cells (Pawelczyk et al. 1996).

\section{Dopamine effects on trophic activity}

Dopamine receptor antagonists such as pimozide and sulpiride enhance mitotic activity and the dopamine receptor agonist bromocriptine inhibits mitotic activity in the anterior pituitary of normal and oestrogen-treated male rats (Stepien et al. 1978, Perez et al. 1986). Increased apoptotic activity in the anterior pituitary of male Fischer rats during the first $44 \mathrm{~h}$ after withdrawal of chronic oestrogen treatment is further enhanced by bromocriptine treatment (Drewett et al. 1993). A similar antiproliferative effect of dopamine agonists on the anterior pituitary is seen in organ culture (Pawlikowski et al. 1978b) and in vivo under basal conditions (Lloyd et al. 1975). Intraventricular injection of the neurotoxin 6-hydroxydopamine, which depletes striatal dopamine, results in a modest increase in pituitary mitotic activity, principally in the acidophilic and chromophobe compartments, when measured 4 and 12 days (but not 2 days) after the injection (Lewinski et al. 1984). The authors speculated that the absence of effect at 2 days was related to a relative increase in hypothalamohypophyseal portal dopamine resulting from early dopaminergic nerve damage. Whether the stimulatory effects of fibroblast growth factor on mitotic index in anterior pituitary explants and the inhibitory effects of bromocriptine on fibroblast growth factor-induced mitosis affect the same cells remains open to speculation (Pawlikowski \& Stepien 1979).

\section{The effects of GH- and corticotrophin-releasing hormones, glucocorticoids and vasopressin on pituitary trophic activity}

GH-releasing hormone (GHRH) has trophic activity in the human (Guillemin et al. 1982, Thorner et al. 1982, Billestrup et al. 1986, Sano et al. 1988) and mouse pituitary (Mayo et al. 1988, Asa et al. 1990, 1992b, Struthers et al. 1991, Lloyd et al. 1992). Prolonged exposure to relatively high levels of GHRH may be limited to hyperplasia (Ezzat et al. 1994) or induce true somatotroph adenoma formation (Asa et al. 1984, Bevan et al. 1989a). Ultimately, however, the distinction might not be relevant, as hyperplasia and adenoma formation may not be distinct processes (Derwahl \& Studer 2001). 

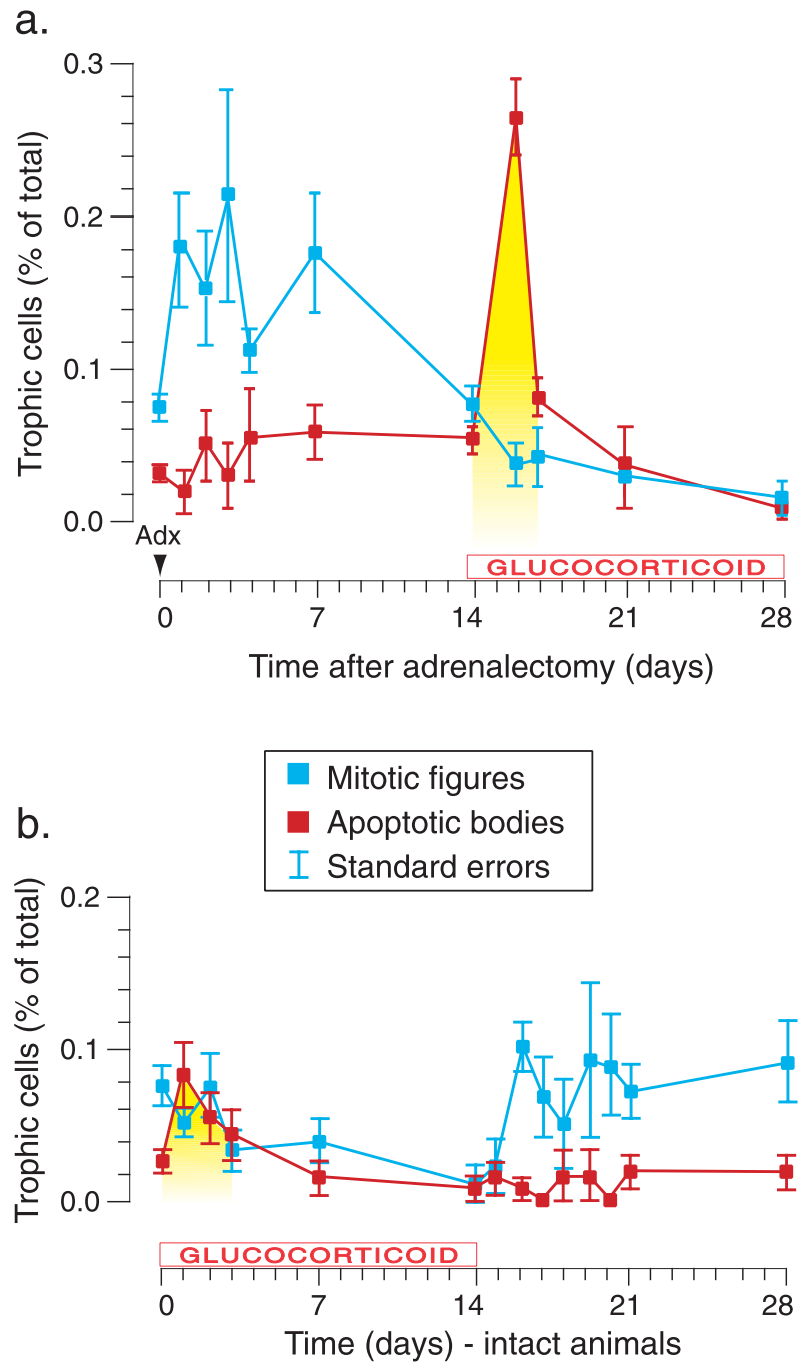

Figure 3 The effects of high-dose glucocorticoids on anterior pituitary mitotic and apoptotic activity in male Wistar rats. (a) The effects of adrenalectomy and subsequent high-dose glucocorticoid replacement on mitotic and apoptotic activity. (b) The effect of high-dose glucocorticoid treatment and glucocorticoid withdrawal in intact controls. Redrawn from Nolan \& Levy (2001).

Glucocorticoid-induced apoptotic bursts are highlighted in yellow.

Corticotrophin-releasing hormone (CRH) has unequivocal trophic potential in the pituitary (Carey et al. 1984, Childs et al. 1995) and chronic administration has been associated with increased corticotroph numbers (Gertz et al. 1987, Asa et al. 1992a), corticotroph nodular hyperplasia (in untreated Addison's disease) (Scheithauer et al. 1983) and, in a single case report of an intrasellar CRH-producing gangliocytoma, with corticotroph adenoma formation (Saeger et al. 1994). On its own at low concentrations, arginine vasopressin (AVP) is a more potent inducer of bromodeoxyuridine uptake into rat anterior pituitary cells than $\mathrm{CRH}$, and low levels of $\mathrm{CRH}$ a.

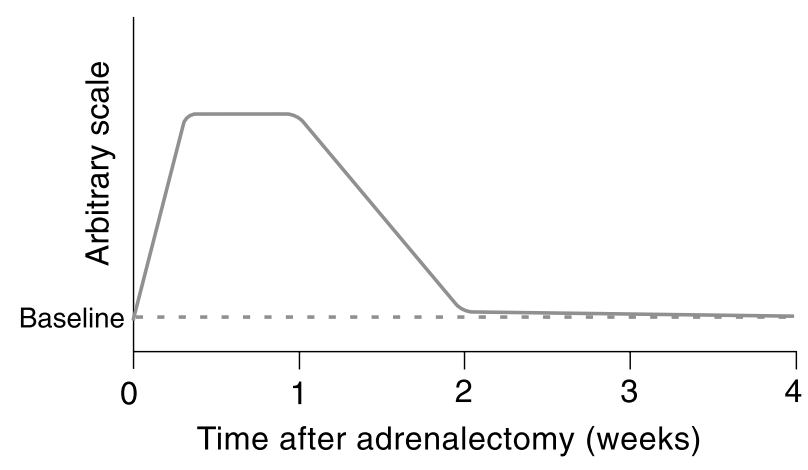

b.

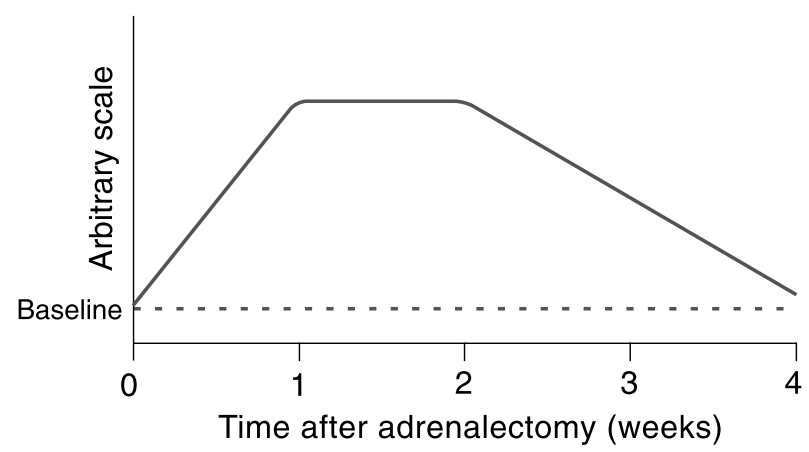

Figure 4 Schematic diagram of changes in pituitary mitotic activity and apoptotic responsiveness to glucocorticoids following bilateral adrenalectomy. (a) Changes in the prevalence of mitotic activity over time, with a peak from 3 to 7 days returning spontaneously to levels seen in intact animals by 2 weeks. (b) Time-related changes in the size of the populations of cells that undergo glucocorticoid-inducible apoptosis after adrenalectomy. A progressive increase during the first week reaches a plateau between 1 and 2 weeks after adrenalectomy before declining to levels seen in untreated intact animals at 4 weeks.

enhance low-dose AVP-induced bromodeoxyuridine incorporation (McNicol et al. 1990).

The effects of adrenalectomy and glucocorticoid replacement on trophic activity in the rat anterior pituitary gland have been investigated for over 20 years (Stepien et al. 1981). Using simultaneous immunohistochemistry for adrenocorticotrophin and bromodeoxyuridine, the latter given as a bolus $3 \mathrm{~h}$ before the animals were killed, overall mitotic activity has been shown to increase during the week after adrenalectomy and decrease again by 2 weeks leading to a $1 \cdot 5$-fold increase in the number of immunocytochemically identifiable corticotrophs (Taniguchi et al. 1995, Nolan et al. 1998). Closely associated with the transient increase in mitotic activity, maximal between 3 and 7 days post-adrenalectomy (Fig. 3a), is a progressive increase in the population of 


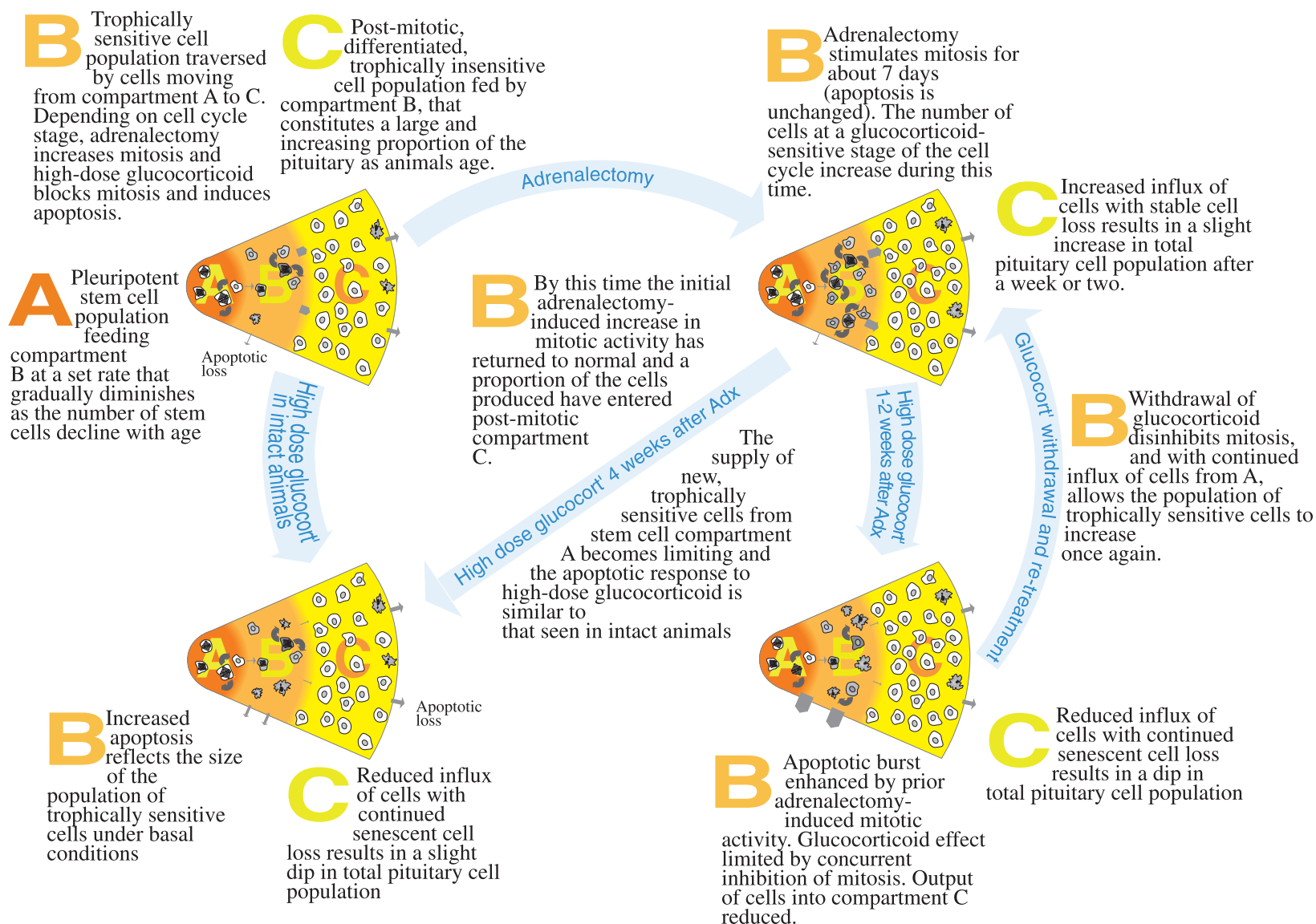

Figure 5 Model of pituitary trophic responses to high-dose glucocorticoid treatment and withdrawal showing the response to adrenalectomy.

cells that undergo apoptosis in response to dexamethasone (compare the heights of the early $(\leq 72 \mathrm{~h}$ ) dexamethasone-induced apoptotic responses in Fig. 3a and $\mathrm{b}$ ). This dexamethasone-sensitive population reaches maximum size after the mitotic peak and plateaus at three times sham-operated controls between 1 and 2 weeks post-adrenalectomy before spontaneously returning to baseline levels by 4 weeks post-surgery (Fig. 4). This suggests that mitotic activity is not only temporally constrained, in as much as it changes for a limited and reproducible period after adrenalectomy despite continued absence of corticosterone and continued elevation of CRH transcription, but also that mitotic and apoptotic activity in the pituitary are closely linked to each other, at least under these circumstances, with apoptotic sensitivity seemingly confined to cells that have entered the cell cycle within the previous 7 to 14 days (Fig. 5) (Nolan \& Levy 2001).

\section{Other potential trophic modulators}

Prostaglandins have complex effects on many aspects of pituitary and hypothalamic function, including modu- lation of interleukin 1-stimulated CRH release (Watanobe et al. 1995) and stimulation of plasma prolactin levels when injected intracerebroventricularly (Costa et al. 1979, Tojo et al. 1986). Indomethacin, an inhibitor of prostaglandin synthesis, inhibits oestrogen-induced DNA synthesis in the rat anterior pituitary gland (Pawlikowski et al. 1981), yet intracerebroventricular injection of prostaglandin $E_{2}$ itself seems to result in a significant decrease of mitotic activity in anterior pituitary chromophobic cells (Sewerynek et al. 1986).

The trophic effects of oestradiol in vivo on pituitary cells was found to be enhanced by concurrent treatment with the peripheral benzodiazepine receptor ligand 4' chlorodiazepam (Ro 5-4864) but not by the centraltype benzodiazepine receptor antagonist Ro 15-1788 (Stepien et al. 1986). A single injection of diazepam reduced anterior pituitary cell mitotic activity in 11-day-old female rat pups (Pawlikowski et al. 1987) and was found to suppress tritiated thymidine uptake in vitro (Kunert-Radek et al. 1994). These findings suggest that benzodiazepine receptors may be involved in the control of pituitary cell proliferation. If so, the cell type involved and the physiological consequences of 
benzodiazepine use at the level of the pituitary remain unknown.

Stimulation of tritiated thymidine incorporation into rat pituitary tumour cells has been demonstrated for gastrin fragments (Pawlikowski et al. 1992), and tritiated thymidine incorporation into normal rat anterior pituitary cells stimulated by angiotensin II. Saralasin, an angiotensin II antagonist, has been found to suppress angiotensin II-induced mammotroph proliferation in some (Shinkai \& Ooka 1995) but not all studies (Pawlikowski \& Kunert-Radek 1997).

In summary, until stable, non-secreted, simultaneously identifiable and easily distinguishable markers for each different anterior pituitary cell type become available, distinguishing between transdifferentiation, quantitative fluxes in relative hormone gene expression in pleuripotent cells, maturation of previously uncommitted cells and physiological and potentially pathophysiological trophic responses within the pituitary will remain a technical impasse (Levy 2000, 2001, Derwahl \& Studer 2001). While it does, the long-term consequences of short-term fluctuation in pituitary trophic activity will remain obscure and, for example, the utility of using array technology to identify quantitative differences in gene expression between the normal pituitary and pituitary adenomas will continue to be hampered by difficulty in correcting for cell-specific variations amplified by polarization of cell populations in clonal expansions. This fundamental goal is nevertheless important to pursue as the effects on pituitary responsiveness of age, sex and temporally different patterns of pharmacological interventions such as intermittent glucocorticoid exposure, as well as potential insights into the pathogenesis of pituitary adenomas, may depend on it.

\section{References}

Abram M, Brue T, Morange I, Girard N, Guibout M \& Jaquet P 1992 Pituitary tumor syndrome and hyperprolactinemia in peripheral hypothyroidism. Annales d'Endocrinologie 53 215-223.

Alkhani AM, Cusimano M, Kovacs K, Bilbao JM, Horvath E \& Singer W 1999 Cytology of pituitary thyrotroph hyperplasia in protracted primary hypothyroidism. Pituitary 1 291-295.

Asa SL, Penz G, Kovacs K \& Ezrin C 1982 Prolactin cells in the human pituitary. A quantitative immunocytochemical analysis. Archives of Pathology and Laboratory Medicine 106 360-363.

Asa SL, Scheithauer BW, Bilbao JM, Horvath E, Ryan N, Kovacs K, Randall RV, Laws ERJ, Singer W, Linfoot JA, Thorner PM \& Vale W 1984 A case for hypothalamic acromegaly: a clinicopathological study of six patients with hypothalamic gangliocytomas producing growth hormone-releasing hormone. Journal of Clinical Endocrinology and Metabolism 58 796-803.

Asa SL, Kovacs K, Stefaneanu L, Horvath E, Billestrup N, Gonzalez-Manchon \& Vale W 1990 Pituitary mammosomatotroph adenomas develop in old mice transgenic for growth hormonereleasing hormone. Proceedings of the Society for Experimental Biology and Medicine 193 232-235.

Asa SL, Kovacs K, Hammer GD, Liu B, Roos BA \& Low MJ $1992 a$ Pituitary corticotroph hyperplasia in rats implanted with a medullary thyroid carcinoma cell line transfected with a corticotropin-releasing hormone complementary deoxyribonucleic acid expression vector. Endocrinology 131 715-720.

Asa SL, Kovacs K, Stefaneanu L, Horvath E, Billestrup N, Gonzalez-Manchon C \& Vale W $1992 b$ Pituitary adenomas in mice transgenic for growth hormone-releasing hormone. Endocrinology $1312083-2089$.

Bergland RM, Ray BS \& Torack RM 1968 Anatomical variations in the pituitary gland and adjacent structures in 225 human autopsy cases. Journal of Neurosurgery 28 93-99.

Bevan JS, Asa SL, Rossi ML, Esiri MM, Adams CB \& Burke CW $1989 a$ Intrasellar gangliocytoma containing gastrin and growth hormone-releasing hormone associated with a growth hormonesecreting pituitary adenoma. Clinical Endocrinology 30 213-234.

Bevan JS, Sussman J, Roberts A, Hourihan M \& Peters JR 19896 Development of an invasive macroprolactinoma: a possible consequence of prolonged oestrogen replacement. Case report. British Journal of Obstetrics and Gynaecology 96 1440-1444.

Bilaniuk LT, Moshang T, Cara J, Weingarten MZ, Sutton LN, Samuel LR \& Zimmerman RA 1985 Pituitary enlargement mimicking pituitary tumor. Journal of Neurosurgery 63 39-42.

Billestrup N, Swanson LW \& Vale W 1986 Growth hormonereleasing factor stimulates proliferation of somatotrophs in vitro. PNAS 83 6854-6857.

Brandle M \& Schmid C 2000 Galactorrhoea and pituitary mass: a typical prolactinoma? Postgraduate Medical Journal 76 232-234.

Carbajo-Perez E \& Watanabe YG 1990 Cellular proliferation in the anterior pituitary of the rat during the postnatal period. Cell and Tissue Research 261 333-338.

Carbajo-Perez E, Carbajo S, Orfao A, Vicente-Villardon JL \& Vazquez R 1991 Circadian variation in the distribution of cells throughout the different phases of the cell cycle in the anterior pituitary gland of adult male rats as analysed by flow cytometry. Journal of Endocrinology 129 329-333.

Carey RM, Varma SK, Drake JCR, Thorner MO, Kovacs K, Rivier J \& Vale W 1984 Ectopic secretion of corticotropin-releasing factor as a cause of Cushing's syndrome; a clinical, morphologic and biochemical study. New England Journal of Medicine 311 381-388.

Castro M, Figueiredo F \& Moreira AC 1995 Time-course of hypothalamic $\mathrm{CRH}$ and pituitary $\mathrm{ACTH}$ contents, and pituitary responsiveness to $\mathrm{CRH}$ stimulation after bilateral adrenalectomy. Hormone and Metabolic Research 27 10-15.

Childs GV 1987 Cytochemical studies of the regulation of ACTH secretion. Annals of the New York Academy of Sciences 512 248-274.

Childs GV, Rougeau D \& Unabia G 1995 Corticotropin-releasing hormone and epidermal growth factor: mitogens for anterior pituitary corticotropes. Endocrinology 136 1595-1602.

Costa G, De Pasquale R, Abate F, Trovato A \& Galati EM 1979 Effects of some prostaglandins on plasma levels of prolactin in the rat. Bollettino della Societa Italiana di Biologia Sperimentale $\mathbf{5 5}$ 1485-1491.

Dada MO, Campbell GT \& Blake CA 1984 Pars distalis cell quantification in normal adult male and female rats. Journal of Endocrinology 101 87-94.

Denef C, Tilemans D \& Andries M 1990 Paracrine control of cell mitosis of lactotrophs, somatotrophs and corticotrophs by growth factors secreted by gonadotrophs in the immature rat adenohypophysis. Proceedings of the 5th Meeting of the European Neuroendocrine Association. Journal of Endocrinological Investigation 14 (Suppl 4-6) 9.

Denk CC, Onderoglu S, Ilgi S \& Gurcan F 1999 Height of normal pituitary gland on MRI: differences between age groups and sexes. Okajimas Folia Anatomica Japonica 76 81-87.

Derwahl M \& Studer H 2001 Hyperplasia versus adenoma in endocrine tissues: are they different? Trends in Endocrinology and Metabolism 13 23-28.

Dinc H, Esen F, Demirci A, Sari A \& Resit Gumele H 1998 Pituitary dimensions and volume measurements in pregnancy and post partum. MR assessment. Acta Radiologica 39 64-69. 
Drewett N, Jacobi JM \& Lloyd HM 1993 Apoptosis in the anterior pituitary gland of the rat: studies with estrogen and bromocriptine. Neuroendocrinology 57 89-95.

Elster AD, Sanders TG, Vines FS \& Chen MY 1991 Size and shape of the pituitary gland during pregnancy and post partum: measurement with MR imaging. Radiology 181 531-535.

Ezzat S, Asa SL, Stefaneanu L, Whittom R, Smyth HS, Horvath E, Kovacs K \& Frohman LA 1994 Somatotroph hyperplasia without pituitary adenoma associated with a long standing growth hormonereleasing hormone-producing bronchial carcinoid. Journal of Clinical Endocrinology and Metabolism 78 555-560.

Friend JP 1979 Cell size and cell division of the anterior pituitary: time course in the growing rat. Experientia 35 1577-1578.

Garcia MM \& Kapcala LP 1995 Growth of a microprolactinoma to a macroprolactinoma during estrogen therapy. Journal of Endocrinological Investigation 18 450-455.

Gertz BJ, Contreras LN, McComb DJ, Kovacs K, Tyrrell JB \& Dallman MF 1987 Chronic administration of corticotropin-releasing factor increases pituitary corticotroph number. Endocrinology 120 381-388.

Gonzalez JG, Elizondo G, Saldivar D, Nanez H, Todd LE \& Villarreal JZ 1988 Pituitary gland growth during normal pregnancy: an in vivo study using magnetic resonance imaging. American Journal of Medicine 85 217-220.

Gratzner HG 1982 Monoclonal antibody to 5-bromo- and 5-iododeoxyuridine: a new reagent for detection of DNA replication. Science 218 474-475.

Guillemin R, Brazeau P, Böhlen P, Esch F, Ling N \& Wehrenberg W 1982 Growth hormone-releasing factor from a human pancreatic tumor that caused acromegaly. Science 218 585-587.

Haggi ES, Torres AI, Maldonado CA \& Aoki A 1986 Regression of redundant lactotrophs in rat pituitary gland after cessation of lactation. Journal of Endocrinology 111 367-373.

Horvath E, Lloyd RV \& Kovacs K 1990 Propylthiouracyl-induced hypothyroidism results in reversible transdifferentiation of somatotrophs into thyroidectomy cells. A morphological study of the rat pituitary including immunoelectron microscopy. Laboratory Investigation 63 511-520.

Inoue K, Tanaka S \& Kurosumi K 1985 Mitotic activity of gonadotropes in the anterior pituitary of the castrated male rat. Cell and Tissue Research 240 271-276.

Khar A, Debeljuk L \& Jutisz M 1978 Effect of hypothalamic extracts on the incorporation of $\left[{ }^{3} \mathrm{H}\right]$-thymidine by pituitary cells in culture. Proceedings of the Society for Experimental Biology and Medicine 158 471-474.

Kineman RD, Faught WJ \& Frawley LS 1992 Steroids can modulate transdifferentiation of prolactin and growth hormone cells in bovine pituitary cultures. Endocrinology 130 3289-3294.

Kolopp M, Poirel G, Vit P \& Perentes E 1992 In situ analysis of adenohypophysis proliferative activity in beagle dogs. Preliminary results. Pathology Research and Practice 188 663-667.

Komolov IS, Fazekas I, Morozova LG, Rappay G \& Fedotov VP 1978 Effect of thyroliberin (thyrotropin releasing hormone) on the proliferation of adenohypophysis cells in monolayer culture. Problemy Endokrinologii 24 60-62.

Kulig E, Jin L, Qian X, Horvath E, Kovacs K, Stefaneanu L, Scheithauer BW \& Lloyd RV 1999 Apoptosis in nontumorous and neoplastic human pituitaries: expression of the Bcl-2 family of proteins. American Journal of Pathology 154 767-774.

Kunert-Radek J \& Pawlikowski M 1975 The effect of thyrotropin releasing hormone on cell proliferation in the anterior pituitary gland of thyroidectomized rats. Neuroendocrinology 17 92-95.

Kunert-Radek J, Stepien H \& Pawlikowski M 1994 Inhibition of rat pituitary tumor cell proliferation by benzodiazepines in vitro. Neuroendocrinology 59 92-96.

Levy A 2000 Is monoclonality in pituitary adenomas synonymous with neoplasia? Clinical Endocrinology 52 393-397.
Levy A 2001 Monoclonality of endocrine tumours: what does it mean? Trends in Endocrinology and Metabolism 12 301-307.

Lewinski A, Konopacki J, Pawlikowski M, Lewinska MK, Smith NK \& Reiter RJ 1984 Effects of intraventricular injections of 6-hydroxydopamine on anterior pituitary cell proliferation. Anatomical Records 208 421-426.

Lloyd HM, Meares JD \& Jacobi J 1975 Effects of oestrogen and bromocryptine on in vivo secretion and mitosis in prolactin cells. Nature 255 497-498.

Lloyd RV, Jin L, Chang A, Kulig E, Camper SA, Ross BD, Downs TR \& Frohman LA 1992 Morphologic effects of hGRH gene expression on the pituitary, liver, and pancreas of MT-hGRH transgenic mice. An in situ hybridization analysis. American Journal of Pathology 141 895-906.

McNicol AM \& Carbajo-Perez E 1999 Aspects of anterior pituitary growth, with special reference to corticotrophs. Pituitary $1257-268$.

McNicol AM, Murray JE \& McMeekin W 1990 Vasopressin stimulation of cell proliferation in the rat pituitary gland in vitro. Journal of Endocrinology 126 255-259.

Mangili F, Cigala C \& Santambrogio G 1999 Staining apoptosis in paraffin sections. Advantages and limits. Analytical and Quantitative Cytology and Histology 21 273-276.

Mayo KE, Hammer RE, Swanson LW, Brinster RL, Rosenfeld MG \& Evans RM 1988 Dramatic pituitary hyperplasia in transgenic mice expressing a human growth hormone-releasing factor gene. Molecular Endocrinology 2 606-612.

Nolan LA \& Levy A 2001 Anterior pituitary trophic responses to dexamethasone withdrawal and repeated dexamethasone exposures. Journal of Endocrinology 169 263-270.

Nolan LA, Kavanagh E, Lightman SL \& Levy A 1998 Anterior pituitary cell population control: basal cell turnover and the effects of adrenalectomy and dexamethasone treatment. Journal of Neuroendocrinology 10 207-215.

Nolan LA, Lunness HR, Lightman SL \& Levy A 1999 The effects of age and spontaneous adenoma formation on trophic activity in the rat pituitary gland: a comparison with trophic activity in the human pituitary and in human pituitary adenomas. Journal of Neuroendocrinology 11 393-401.

Nouet JC \& Kujas M 1975 Variations of mitotic activity in the adenohypophysis of male rats during a 24-hour cycle. Cell and Tissue Research 164 193-200.

Oishi Y, Okuda M, Takahashi H, Fujii T \& Morii S 1993 Cellular proliferation in the anterior pituitary gland of normal adult rats: influences of sex, estrous cycle, and circadian change. Anatomical Record 235 111-120.

Pawelczyk T, Pawlikowski M \& Kunert-Radek J 1996 Effects of $\mathrm{TRH}$, prolactin and TSH on cell proliferation in the intermediate lobe of the rat pituitary gland. Journal of Endocrinology 148 193-196.

Pawlikowski M \& Stepien H 1979 Effects of fibroblast growth factor and bromocriptine on the mitotic activity of the anterior pituitary gland in organ culture. Cell and Tissue Research 202 165-169.

Pawlikowski M \& Slowinska-Klencka D 1994 Effects of TRH and TRH-like peptides on anterior pituitary cell proliferation in rats. Cytobios 79 117-122.

Pawlikowski M \& Kunert-Radek J 1997 Angiotensin IV stimulates the proliferation of rat anterior pituitary cells in vitro. Biochemical and Biophysical Research Communications 232 292-293.

Pawlikowski M, Stepien H \& Kunert-Radek J 1975 Thyroxine inhibition of the proliferative response of the anterior pituitary to thyrotropin releasing hormone in vitro. Neuroendocrinology $\mathbf{1 8}$ 277-280.

Pawlikowski M, Kunert-Radek J, Mroz-Wasilewska Z \& Stepien H $1978 a$ The influence of LHRH on the anterior pituitary mitotic activity. Endokrynologia Polska 29 1-6.

Pawlikowski M, Kunert-Radek J \& Stepien H 1978 b Direct antiproliferative effect of dopamine agonists on the anterior pituitary gland in organ culture. Journal of Endocrinology 79 245-246. 
Pawlikowski M, Kunnert-Radek J \& Stepien H 1978c Somatostatin inhibits the mitogenic effect of thyroliberin. Experientia 34 271-272.

Pawlikowski M, Kunert-Radek J, Lewinski A \& Karasek E 1981 Indomethacin inhibits the estrogen-induced DNA synthesis in the rat anterior pituitary gland. Biochemical and Biophysical Research Communications 101 1052-1056.

Pawlikowski M, Stepien H, Mroz-Wasilewska Z \& Pawlikowska A 1987 Effects of diazepam on cell proliferation in cerebral cortex, anterior pituitary and thymus of developing rats. Life Science $\mathbf{4 0}$ $1131-1135$

Pawlikowski M, Kunert-Radek J \& Dohler KD 1992 Stimulation of rat pituitary tumoral cell proliferation in vitro by tetra- and pentagastrin. Endokrynologia Polska 43 469-473.

Pawlikowski M, Kunert-Radek J, Grochal M, Zielinski K \& Kulig A 1997 The effect of somatostatin analog octreotide on diethylstilbestrol-induced prolactin secretion, cell proliferation and vascular changes in the rat anterior pituitary gland. Histology and Histopathology 12 991-994.

Perez RL, Machiavelli GA, Romano MI \& Burdman JA 1986 Prolactin release, oestrogens and proliferation of prolactin-secreting cells in the anterior pituitary gland of adult male rats. Journal of Endocrinology 108 399-403.

Quintanar-Stephano A \& Valverde C 1997 Mitogenic effects of thyroxine and TRH on thyrotrophs and somatotrophs of the anterior pituitary gland in thyroidectomized rats. Journal of Endocrinology 154 149-153.

Saeger W, Puchner MJA \& Ludecke DK 1994 Combined sellar gangliocytoma and pituitary adenoma in acromegaly or Cushing's disease: a report of 3 cases. Virchows Archives 425 93-99.

Sano T, Asa SL \& Kovacs K 1988 Growth hormone-releasing hormone-producing tumors: clinical, biochemical, and morphological manifestations. Endocrine Reviews 9 357-373.

Scheithauer BW, Kovacs K \& Randall RV 1983 The pituitary gland in untreated Addison's disease. A histologic and immunocytologic study of 18 adenohypophyses. Archives of Pathology and Laboratory Medicine 107 484-487.

Senogles SE 1994 The D2 dopamine receptor mediates inhibition of growth in GH4ZR7 cells: involvement of protein kinase-C epsilon. Endocrinology 134 783-789.

Sewerynek E, Lewinski A, Konopacki J, Pawlikowski M \& Lewinska MK 1986 Effect of intracerebroventricular injection of prostaglandin E2 on anterior pituitary cell proliferation. Research in experimental medicine. Zeitschrift für die Gesamte Experimentelle Medizin Einschliesslich Experimenteller Chirurgie 186 1-4.

Shinkai T \& Ooka H 1995 Effect of angiotensin II on the proliferation of mammotrophs from the adult rat anterior pituitary in culture. Peptides 16 25-29.

Shinkai T, Sakurai Y \& Ooka H 1995 Age-related changes in the numbers of mammotrophs, somatotrophs and mammosomatotrophs in the anterior pituitary gland of female rats: a flow cytometric study. Mechanisms of Ageing and Development 83 125-131.

Shirasawa N \& Yoshimura F 1982 Immunohistochemical and electron microscopical studies of mitotic adenohypophysial cells in different ages of rats. Anatomy and Embryology 165 51-61.

Stefaneanu L, Kovacs K, Lloyd RV, Scheithauer BW, Young WFJ, Sano T \& Jin L 1992 Pituitary lactotrophs and somatotrophs in pregnancy: a correlative in situ hybridization and immunocytochemical study. Virchows Archives B, Cell Pathology including Molecular Pathology 62 291-296.

Stepien H, Wolaniuk A \& Pawlikowski M 1978 Effects of pimozide and bromocriptine on anterior pituitary cell proliferation. Journal of Neural Transmission 42 239-244.

Stepien H, Karasek E \& Pawlikowski M 1981 Effects of adrenalectomy and hydrocortisone on DNA synthesis in the rat anterior pituitary gland. Biochemical and Biophysical Research Communications 100 1531-1536.

Stepien H, Kunert-Radek J \& Pawlikowski M 1986 Enhancement of estradiol-induced DNA synthesis in the anterior pituitary gland by the peripheral-type benzodiazepine receptor ligand Ro 5-4864. Journal of Neural Transmission 66 303-307.

Struthers RS, Vale WW, Arias C, Sawchenko PE \& Montminy MR 1991 Somatotroph hypoplasia and dwarfism in transgenic mice expressing a non-phosphorylatable CREB mutant. Nature $\mathbf{3 5 0}$ $622-624$.

Surks MI \& DeFesi CR 1977 Determination of cell number of each cell type in the anterior pituitary of euthyroid and hypothyroid rats. Endocrinology 101 946-958.

Taniguchi Y, Tamatani R, Yasutaka S \& Kawarai Y 1995 Proliferation of pituitary corticotrophs following adrenalectomy as revealed by immunocytochemistry combined with bromodeoxyuridine-labeling. Histochemistry 103 127-130.

Thorner MO, Perryman RL, Cronin MJ, Rogol AD, Draznin M, Johanson A, Vale W, Horvath E \& Kovacs K 1982 Somatotroph hyperplasia: successful treatment of acromegaly by removal of a pancreatic islet tumor secreting a growth hormone releasing factor. Journal of Clinical Investigation 70 965-977.

Thorner MO, Chapman IM, Gaylinn BD, Pezzoli SS \& Hartman ML 1997 Growth hormone-releasing hormone and growth hormonereleasing peptide as therapeutic agents to enhance growth hormone secretion in disease and aging. Recent Progress in Hormone Research $\mathbf{5 2}$ 215-244.

Tilemans D, Andries M \& Denef C 1992 Luteinizing hormonereleasing hormone and neuropeptide $\mathrm{Y}$ influence deoxyribonucleic acid replication in three anterior pituitary cell types. Evidence for mediation by growth factors released from gonadotrophs. Endocrinology 130 882-894.

Tojo K, Kato Y, Kabayama Y, Ohta H, Inoue T \& Imura H 1986 Further evidence that central neurotensin inhibits pituitary prolactin secretion by stimulating dopamine release from the hypothalamus. Proceedings of the Society for Experimental Biology and Medicine $\mathbf{1 8 1}$ $517-522$.

Toni R \& Vitale M 2000 The role of flow cytometry in the study of cell growth in the rat anterior pituitary gland. European Journal of Histochemistry 44 315-324.

Vidal S, Horvath E, Kovacs K, Cohen SM, Lloyd RV \& Scheithauer BW 2000 Transdifferentiation of somatotrophs to thyrotrophs in the pituitary of patients with protracted primary hypothyroidism. Virchows Archives 436 43-51.

Vidal S, Horvath E, Kovacs K, Lloyd RV \& Smyth HS 2001 Reversible transdifferentiation: interconversion of somatotrophs and lactotrophs in pituitary hyperplasia. Modern Pathology 14 20-28.

Watanobe H, Sasaki S \& Takebe K 1995 Role of prostaglandins E1, $\mathrm{E} 2$ and F2 alpha in the brain in interleukin 1 beta-induced adrenocorticotropin secretion in the rat. Cytokine 7 710-712.

Westlund KN, Aguilera G \& Childs GV 1985 Quantification of morphological changes in pituitary corticotropes produced by in vivo corticotropin-releasing factor stimulation and adrenalectomy. Endocrinology 116 439-445.

Wynick D, Critchley R, Venetikou MS, Burrin JM \& Bloom SR 1990a Purification of functional lactotrophs and somatotrophs from female rats using fluorescence-activated cell sorting. Journal of Endocrinology 126 269-274.

Wynick D, Venetikou MS, Critchley R, Burrin JM \& Bloom SR $1990 \mathrm{~b}$ Flow cytometric analysis of functional anterior pituitary cells from female rats. Journal of Endocrinology 126 261-268.

Received 25 February 2002

Accepted 29 April 2002 